\title{
ISLAM JAWA IN DIASPORA AND QUESTIONS ON LOCALITY
}

\author{
Maftukhin \\ IAIN Tulungagung - Indonesia | maftuh_in17@yahoo.com
}

\begin{abstract}
This article examines the translocal Islam Jawa (Javanese Islam) that characterises the deterritorialisation of culture through space and time. Contrary to mainstream approaches to Islam Jawa that tends substantially picture Islam and Muslim in Java as a mere "localised form of Islam", it sees Islam Jawa as a "translocal" practices. In addition, it sees that the idea of Islam Jawa travels, deterritorialises, and reterritorialises in different times and places. Therefore, what is imagined by scholars as "local Islam" is not local in traditional and geographical senses because Islam Jawa is formed, shaped and influenced by the mobility, entanglement, connectivity across oceans, regions, and borders. The Islam Jawa also travels to a different place, transcending the modern limits of nation-states' boundaries. Islam Jawa is a product and a consequence of the efforts to establish between "imagined" spatial and temporal congruence.
\end{abstract}

Keywords: Translocality, Islam Jawa, Javanese Muslim

\section{Introduction}

Along with the rising interest to study Islam as discursive tradition, pioneered mainly by a renowned Anthropologist Talal Asad, ${ }^{1}$ there has been an emerging paradigm in social sciences as a continuation of further development in the study of geography, particularly since the introduction of the geography of humanities in the 1980s. In socialhumanities studies, the "spatial turn" reflects this new development and following the turn, terms and concepts also emerge and become

1 Talal Asad, The Idea of an Anthropology of Islam (Washington DC: Centre for Contemporary Arab Studies, 1986); Ovamir Anjum, "Islam as a Discursive Tradition: Talal Asad and His Interlocutors," Comparative Studies of South Asia, Africa, the Middle East 27, no. 3 (2007): 656-672. 
popular among academia, such as the notion of heterotopias, ${ }^{2}$ scape, and translocality. ${ }^{3}$ Through his Modernity at Large, Appadurai used translocality both in opposition to and yet as a potentially constitutive element of locality. Locality is understood as the grounded neighbourhood sites of traditional ethnographic inquiry. For Appadurai, translocality differs from migrant ethnic enclaves but nonetheless influence the development of identities within them. They are imagined or virtual neighbourhoods that emerge at the articulation of media and mobility. As a product of the increased global mobility of transnational migrants, Appadurai depicts translocality as "deterritorialized imaginings" of ethnonational identity formation that implode into actual migrant ethnic enclaves, becoming agents in the production of a new sense of locality un-moored from the pull of the nation-state in which the real enclaves are located. ${ }^{4}$

Appadurai's theoretical formulation of translocality focuses on the role of mass media and other modes of cultural globalisation in shaping transnational migrant identities rather than their identities being enacted through their own actual socioeconomic and political practices. Like Appadurai, Hannerz understands translocality largely in terms of heightened mobility rather than the situatedness of migrating subjects. According to him, translocality draws attention to actors, be it in the forms of kinship, individuals, social movements, whose activities and relationship transcend national boundaries. ${ }^{5}$ In Transnational Research, Hannerz views translocalities as sites that are "intensely involved in mobility and in the encounters of various kinds of mobile people..." Such spaces of encounter also tend to be "nodes" connecting transnational social and cultural processes. ${ }^{6}$

A German historian, Ulrieke Freitag also uses the term "translocal" to invest the historical entanglements between different non-European regions in, for example, Africa or Southeast Asia. ${ }^{7}$ The focus is on the

\footnotetext{
2 Michel Foucault, "Different Spaces," in The Essential Works of Michel Foucault, 19541984, ed. James D. Faubion (New York: The New Press, 1997), 175-185.

3 Arjun Appadurai, Modernity at Large: Cultural Dimensions of Globalization (Minneapolis: University of Minnesota Press, 1996).

${ }^{4}$ Ibid., 192-196.

5 Ulf Hannerz, "Transnational Research," in Handbook of Methods in Cultural Anthropology, ed. H. Russell, Bernard (Walnut Creek: Altamira, 1998), 235-258.

${ }^{6}$ Ibid.

${ }^{7}$ Ulrike Freitag and Achim von Oppen, "Introduction: 'Translocality': An Approach to Connection and Transfer in Area Studies," in Translocality: The Study of Globalising
} 
mobility of actors, ideas, commodities, and artefacts between the various parts of the South and the consequences of exchange, circulation, and transfer beyond real or imagined boundaries. The emphasis is not on crossing national borders, but on overcoming spatial differences. In this context, it is stressed that there are many boundaries, inside and outside the nation-state, which are likewise important. There is rather a multiplicity of borders, which are not necessarily political, but economic, social, religious, and else. ${ }^{8}$ In a similar manner as the 'field', space in Islamic studies has been treated as an undefined meta-category up till today. Common terms like 'Moroccan Islam', 'South Asian Islam', ${ }^{10}$ 'African Islam',11 'American Islam',12 or 'Euro-Islam',13 underline the local distinctiveness of Muslim identities and have the tendency to reproduce a close spatial relationship between a geographical site and specific religious expressions. These spatial terms, implicitly or explicitly, disregard mobilities, movements and historical networks of pilgrimage or trade which crosses regional boundaries and triggered religious, economic and cultural exchange between Muslim communities. Against the background of globalisation studies and transnational Islamic movements, many authors today turn towards the interconnections and translocal space of Muslim. Engseng Ho, for instance, takes the Yemeni region of Hadramaut as a starting point to illustrate travel, mobility and Hadrami communities dispersed over the Indian Ocean. ${ }^{14}$ An emerging Indonesian scholar as well as an assistant professor at New York University (NYU), Ismail Fajrie Alatas also follows this theoretical route through tracing the genealogy, travelling text and

Processes from a Southern Perspective, ed. Ulrike Freitag and Achim von. Oppen (Leiden \& Boston: Brill, 2010).

8 Ibid.

${ }^{9}$ Dale F. Eickelman, Moroccan Islam: Tradition and Society in a Pilgrimage Center (Texas: University of Texas Press, 1981).

10 Katherine Pratt Ewing, Shariat and Ambiguity in South Asian Islam (Berkeley: University of California Press, 1988).

11 Eva Evers Rosander and David Westerlund, African Islam and Islam in Africa: Encounters between Sufis and Islamists (Ohio: Ohio University Press, 1997).

12 Paul Barrett, American Islam: The Struggle for the Soul of a Religion (New York, etc.: Picador, 2007).

${ }^{13}$ Nezar AlSayyad and Manuel Castells, Muslim Europe or Euro-Islam: Politics, Culture, and Citizenship in the Age of Globalization (Lexington: Lexington Books, 2002).

${ }_{14}$ Engseng Ho, The Graves of Tarim: Genealogy and Mobility Across the Indian Ocean, California World History Library (California: University of California Press, 2006). 
people and ritualisation that contribute to the establishment of authority of a hadrami-sada Sufi scholar in contemporary Central Java. ${ }^{15}$

This article deals with the deterritorialisation and reterritorialisation of tradition by looking at the notion of Islam Jawa in its new homelands. Rather than examining the substantive notion of Islam Jawa, it examines how Islam Jawa becomes deterritorialisation and reterritorialisation in a context beyond its geographical origin. The concept of translocality is a fruitful theory as it offers a new light to do justice to a tradition that travels, deterritorialises and reterritorialises across boundaries. Therefore, the article differs from the mainstream approach of Islam Jawa that located Islam -and consequently subdued tradition- into a spatial division whereas the expression outside the limit of place and the boundary is often neglected. This article, on the other hand, will delve into the continuity and the significance of tradition and culture in new homelands as consequences of mobility of people that bring with them their particular tradition and culture which are enacted, maintained and practised in new geographical settings. The Islam Jawa, as demonstrated throughout the following discussion, transgresses the boundaries of modern nation-states, thus also highlights the transnational ${ }^{16}$ characteristic of Islam Jawa.

\section{Translocality: Islam Jawa in New Homelands}

There has been a long-standing dualism in the study of the anthropology of Islam that divides between two poles of global vs. local, universal vs. vernacular, orthodox vs. unorthodox, scriptural vs. traditional, urban vs. rural. The sociologist Robert Redfield is highly influential to this dualism construct that defines the "great tradition" as the main reflection of the scripture in contrast to the imperfect appropriation of "little tradition." 17 An American anthropologist, Clifford Geertz applied this dualism through his Islam Observed and demonstrated the traditionalism and scripturalism dichotomies. ${ }^{18}$ In

\footnotetext{
${ }^{15}$ Ismail Fajrie Alatas, "Aligning the Sunna and the Jamā'a: Religious Authority and Islamic Social Formation in Contemporary Central Java, Indonesia" (The University of Michigan, 2016); Ismail Fajrie Alatas, "Pilgrimage and Network Formation in Two Contemporary Bā'alawī Ḥawl in Central Java," Journal of Islamic Studies (May 13, 2014).

16 For discussion on transnational tradition see for instance Peter G. Mandaville, Transnational Muslim Politics: Reimagining the Umma (Oxon: Routledge, 2003).

${ }_{17}$ Robert Redfield, Peasant Society and Culture (Chicago: University of Chicago Press, 1956).

18 Clifford Geertz, Islam Observed: Religious Development in Morocco and Indonesia, A Phoenix book (Chicago: University of Chicago Press, 1968).
} 
the same tone, Ernest Gellner's Muslim Society refashioned the dualism into a spatial framework with which he distinguished between urban and rural Islam. Rural Islamic society revolves around saintly figures and holy men, whereas the scripture has shaped the urban Islam. ${ }^{19}$

Clifford Geertz is the most influential anthropologist observing religious expressions in Java through his seminal The Religion of Java. He classifies three dichotomised poles of Javanese religion (agama Jawa): the priyayi, abangan, and santri.20 The priyayi refers to a hierarchical category of social structure and implies the higher position of Javanese elites vis-à-vis the commoners. The abangan (from the Javanese word "abang" means "red") refers to those Javanese less strict in their adherence to Muslim devotional forms than the so-called santri, practising scripture version of Islam or "orthodox" Muslims. The larger relationship of Javanism to Islam, however, is a complex matter. Geertz's characterization of abangan culture as deeply Hindu-Buddhist was criticised by, among others, the renowned Islamist Marshall Hodgson. Hodgson wrote: "influenced by the polemics of a certain school of modern Shari'ah-minded Muslims, Geertz identifies Islam only with what that school of modernists happens to approve, and ascribes everything else to an aboriginal or a Hindu-Buddhist background, gratuitously labelling much of the Muslim religious life in Java Hindu. He identifies a long series of phenomena, virtually universal to Islam and sometimes found even in the Qur'an itself, as un-Islamic; and hence his interpretation of the Islamic past as well as of some recent anti-Islamic reactions is highly misleading." 21 Many people referred to by outsiders as abangan studiously avoid the term for self-ascription, since, it is widely regarded as derogatory. Many prefer to refer to themselves as kejawen (Javanist), practitioners of Islam Jawa, or, simply "Muslim," with the understanding that they place more emphasis on the mystical than the legal or ritualistic dimensions of Islam. ${ }^{22}$ Instead of seeing Islam Jawa as relational, many anthropologists consider it as stable, fixed and tangible categories. They tend to

\footnotetext{
${ }^{19}$ Ernest Gellner, "Muslim Society" (Cambridge: Cambridge University Press, 1981).

20 Clifford Geertz, The Religion of Java (Illinois: The Free Press of Glenco, 1960).

${ }^{21}$ Marshall G. S. Hodgson, The Venture of Islam. The Expansion of Islam in the Middle Periods: Conscience and History in a World Civilization (Volume 2) (Chicago: University of Chicago Press, 1974), 551. See also Mark Woodward, Islam in Java: Normative Piety and Mysticism in the Sultanate of Yogyakarta (Arizona: University of Arizona Press, 1989).

${ }_{22} \mathrm{R} \mathrm{W}$ Hefner, "Islam, State, And Civil Society: ICMI and the Struggle for the Indonesian Middle Class," Indonesia 56 (1993): 1-35.
} 
substantialise Islam Jawa, to see it as a substance, thing, organism, or collective individuals, rather than to see it as in relational, processual, dynamic, and disaggregated term.

An American anthropologist, Michael Gilsenan criticises the predisposition arguing that Islam as monolithic practice and calls for an approach that delve into variations of Islam in different societies. ${ }^{23}$ In the meantime, Talal Asad proposes his theoretical frames through the concept of "tradition" as a key concept to understand the changing and varieties of Islamic expressions. According to Asad, Islam is a discursive instrument that continually looks back to its history, scripture, and accumulated discourses to maintain its presence in the midst of present challenges, and to secure its future. A tradition, according to Asad, "consists essentially of discourses that seek to instruct practitioners regarding the correct form and purpose of a given practice that, precisely because it is established, has a history". As such, anthropologists ought to examine the ways through which "Muslims are inducted as Muslims," and how authoritative practices are regulated, upheld, adjusted, and extended. ${ }^{24}$ While Talal Asad's and Gilsenan's theories are important, particularly to answer the question what Islam is and its multiple manifestations, the article argues that the subjects of anthropology of Muslim societies should also include manifestation of Islam in local context while at the same time to avoid the old debates inspired by the dualism model of orthodoxy and heterodoxy. In addition, the local Islam is also local, but the notion of locality does not means that that it is static but dynamic. Islam and the question of locality will be clear if we look at the historical process travelling culture between locals, thus translocal. In other words, it is important to offer, as this article demonstrates, an alternative view that Islam Jawa is 'not local' as connoted by its mentioning because Islam Jawa also travels to new homelands outside Java

The discussion on deterritorialised and reterritorialised Islam Jawa is not novel as some authors did make study on the issue. A study by Tim G. Babcock on Javanese in Tondano is one of example on this issue. Babcock examines the elements of religiosity of Javanese Muslim in Tondano while his approach is highly influenced by the division between priyayi, abangan, and santri model that Clifford Geertz

23 Michael Gilsenan, Recognizing Islam: Religion and Society in the Modern Middle East (London: I. B. Tauris, 1990).

${ }^{24}$ Asad, The Idea of an Anthropology of Islam, 20-22. 
offered. ${ }^{25}$ The book is important in the sense that it offers an ample example of Islam Jawa in a different context, beyond the island of Java as spatially defined. Another author, Pamela Allen, discusses the Islam Jawa among Javanese Muslim in Suriname. ${ }^{26}$ Her article demonstrates that the Islam Jawa is not only circulating between domestic borders or within nation-state, but also it has transnational character. As Allen, the article address through the following discussion the translocal dimension of Islam Jawa outside Indonesia or in diaspora. Thus it is translocal. The case of Javanese migrants in Suriname and elsewhere is without a doubt a significant example of how Islam Jawa travels and is translated beyond the limits of geographical origin. Some important works on this issue include Moch Nur Ichwan study on kiblat among Javanese Muslim in Suriname and the Netherlands, ${ }^{27}$ the slametan among Javanese Muslim in the Netherlands by Khusen. ${ }^{28}$ These two works emphasise that the continuity of cultural expression amid the rapid migration and the tension generated by the movement towards a more orthodox form of Islam.

\section{People, Mobility, and Translocality}

Javanese migration to Suriname began by the end of $19^{\text {th }}$ century. They are mainly labours sent to Suriname to work on the plantations owned by the Dutch. In addition to Suriname, Javanese labours also were recruited to work in British Malaya and French New Caledonia in Melanesia. ${ }^{29}$ The Javanese started to arrive in New Caledonia in 1902. In 1945, there were 7,249 Javanese in New Caledonia. After the World War II, the Javanese were repatriated, except about 3,000 people who decided to stay. In 1987, there was an estimated 6,750 Javanese in New

25 Tim G. Babcock, Kampung Jawa Tondano: Religion and Cultural Identity (Yogyakarta Indonesia: Gadjah Mada University Press, 1989).

26 Pamela Allen, "Javanese Cultural Traditions in Suriname," Review of Indonesian and Malaysian Affairs 45, no. 2011 (2012): 199-223.

${ }_{27}$ Moch Nur Ichwan, "Continuing Discourse on 'Keblat': Diasporic Experiences of the Surinamese Javanese Muslims in the Netherlands," Sharqiyyat 11, no. October 1997 (1999): 101-119.

${ }^{28}$ Moh. Khusen, "Contending Identity In The Islamic Ritual: The Slametan among Surinamese Javanese Muslims in The Netherlands," Al-Jami' ab: Journal of Islamic Studies 43, no. 2 (2005): 283-308.

${ }^{29}$ Pamela Allen, "Diasporic Representations of the Home Culture: Case Studies from Suriname and New Caledonia," Asian Ethnicity 16, no. 3 (2015): 353-370. 
Caledonia, about 4.5 percent of the total population. ${ }^{30}$ Plans to send labours from the Netherland Indies, mainly from the island of Java and Madura, had been set up since the mid-nineteenth century. After several failed efforts, the Council of Netherlands East Indies granted the Nederlandsche Handel-Maatschappij/NHM in Batavia a license to import some hundred labours from Java and Madura to work at its plantation factory in Suriname in the 1880s. ${ }^{31}$ The Dutch colonial authorities permitted the recruitment of indentured labourers beginning in 1890 to increase Suriname's population and to support the growth of plantations. When emigration was terminated in 1939, more than 32,000 Javanese, including women and children, had migrated to Suriname. After finishing the indenture contracts, only around 23.3 percent of them returned to the homeland between 1896 and 1939.32 Two years after Indonesian independence in 1945, about 700 people returned to Indonesia. Then in 1953, another 300 or so families (around 1,200 people) returned to Indonesia and were relocated in West Sumatra province. In other words, most of the immigrants decided -voluntarily or by forced- to stay in Suriname. It is estimated that between 20,000 and 25,000 Javanese-Surinamese migrated to the Netherlands in the 1970s and experienced double migration. 33

Religion and culture have been relevant for the majority of migrant labourers in Suriname. ${ }^{34}$ The Javanese in Suriname number more than 65,000 people (15 percent of the total Suriname population). According to a 1971 census, the Suriname Javanese community numbers close to 60,000; today they comprise nearly 18 percent of Suriname's total population. In 1998, Javanese Surinamese numbered almost 70,000 people (16 percent of the Suriname total population of

\footnotetext{
30 Pamela Allen, "Indonesians Speaking French," Inside Indonesia, last modified 2010, accessed February 9, 2016, http://www.insideindonesia.org/indonesians-speakingfrench.

${ }^{31}$ Rosemarijn Hoefte, In Place of Slavery: A Social History of British Indian and Javanese (Miami etc.: University Press of Florida, 1998), 44-47.

32 E.M. Hendrix and M.A. van Waning, "De Javaanse Moslims in Suriname: Een Kwalitatief Onderzoek Anno 2009" (Universiteit Utrecht, the Netherlands, 2010).

${ }^{33}$ Nathal M. Dessing, Rituals of Birth, Circumcision, Marriage, and Death Among Muslims in the Netherlands (Leuven: Peeters, 2001).

${ }^{34}$ Rosemarijn Hoefte, “The Javanese of Suriname," Inside Indonesia, last modified 2008, accessed January 9, 2016, http://www.insideindonesia.org/the-javanese-of-suriname.
} 
431,303). ${ }^{35}$ Nevertheless, the Javanese in Suriname are economically and socially marginalised. Although coming to Suriname, like the Javanese, as indentured labourers, the East Indians (known locally as Hindustani) were able to improve their economic and social status. The Creoles (mixed white and black), considering themselves part of the dominant group, looked down on the Javanese. 36 The feelings of deprivation and inferiority were internalised in the Javanese interethnic relations and became a crucial factor in their politics of identity. Living under depriving circumstances in Suriname, it is not surprising that the Javanese have strived to maintain their identity. Wolfowitz's study of spoken language by Javanese immigrants to Suriname through examining substantial stylistic and sociolinguistic literature on the Javanese language found out the importance of Javanese language in the construction of Javanese in Suriname. ${ }^{37}$ Examining cultural elements among Javanese migrants in Suriname, Pamela argues Javanese as an ethnic category, and its "culture" do share the different trajectories of boundaries. ${ }^{38}$ Javanese traditions such as slametan (the ritual gathering with food offerings for special occasions such as births, circumcisions, weddings and deaths), ${ }^{39}$ sajen (offerings for the spirits), mitoni (celebration of the seventh month of pregnancy), jaran kepang (horse dance), and wayang (shadow puppet) were well-preserved by the

\footnotetext{
35 Aonghas St-Hilaire, "Ethnicity, Assimilation and Nation in Plural Suriname," Ethnic and Racial Studies 24, no. 6 (January 2001): 998-1019.

36 Parsudi Suparlan, The Javanese in Suriname: Ethnicity in an Ethnically Plural Society (Arizona: Program for Southeast Asian Studies, Arizona State University, 1995).

37 Clare Wolfowitz, Language Style and Social Space: Stylistic Choice in Suriname Javanese (Urbana: University of Illinois Press, 1991).

38 Allen, "Javanese Cultural Traditions in Suriname."

39 Slametan, from Javanese slamet means 'safety and well-being'. It is a religious meal rituals prevalent among Javanese muslim to which Geertz attributed as abangan -less orthodox Islamic or syncretic religious practice. Woodward later contends the argument and sees it as Islam practice -as part of santri culture. Later anthropologist sees slametan as ritual for the well-being of the living, rather than some short of offering for the death. Masdar Hilmy takes a mid-stance while he argues that both viewpoints depart from different settings; the latter in the hearland of Java, while the former in the periphery. See Mark R Woodward, "The 'Slametan': Textual Knowledge and Ritual Performance in Central Javanese Islam," History of Religions 28, no. 1 (1988): 54-89; Masdar Hilmy, "Islam and Javanese Acculturation: Textual and Contextual Analysis of the Slametan Ritual" (McGill University, 1999); Andrew Beatty, Varieties of Javanese Religion. An Anthropological Account (New York: Cambridge Univiversity Press, 1999).
} 
community. ${ }^{40}$ The santris also have their own forms of art, such as terbang Jawa, which consists of musical instruments of hoop-shaped drums with parchment on one side. The santri's presence in the typically abangan cultures such as slametan and wayang were highly valued since they were considered as spiritual leaders. ${ }^{41}$

The glorification of Java has been capitalised upon by Suriname Javanese businesspeople. They have imported cultural commodities, such Javanese clothing, books, cassette tapes and records of traditional and modern music, and traditional medicines from Java. In turn, these cultural materials influence the Surinamese Javanese culture and are proudly presented to other ethnic groups, so that, in a way they have stabilised Javanese identity. Among these cultural materials, the most important is the modern music. Indonesian artists, especially keroncong and Javanese singers as well as modern Javanese mixed pop music campursari have frequently been invited to perform in Suriname. The records of such music sell well there. The keroncong and Javanese pop singers such as Mus Mulyadi and Waldjinah became household names in Javanese Suriname families. Their names currently are being replaced by the superstar Didik Kempot, who also wrote a hit song titled Angin Paramaribo (The Wind of Paramaribo). Some radio and television stations which provide Javanese language programs - such as Garuda Radio and Television, Bersama Radio, Radio Pertjaja, and Mustika Radio and Television-have become the venue of the cultural links between the Suriname Javanese and far away Java. ${ }^{42}$ Some Suriname Javanese nevertheless feel that their culture is inferior to that of Javanese culture in Java. In regards to language, since the Javanese brought to Suriname were laborers of lower social status, they talked Jawa ngoko (lower register Javanese spoken mainly by people of lower status) rather than Jawa kromo inggil (high Javanese register spoken by the Javanese elite). ${ }^{43}$

\footnotetext{
${ }^{40}$ Santo Koesoebjono, "Javanese in Suriname Strive to Preserve Origins," The Jakarta Post, 1999.

${ }^{41}$ G. D. van. Wengen, The Cultural Inheritance of the Javanese in Surinam (Leiden: E.J. Brill, 1975).

42 Putut Widjanarko, "Homeland, Identity and Media: A Study of Indonesian Transnational Muslims in New York City" (Ohio University, 2007).

43 Peter Meel, "Continuity through Diversity: The Surinamese Javanese Diaspora and the Homeland Anchorage," Wadabagei: A Journal of the Caribbean and Its Diaspora 13, no. 3 (2011): 95-134.
} 
Nevertheless, the efforts to maintain particular culture did not happen without some internal conflicts. The Javanese culture and art forms are disintegrating, especially among urban youths. This younger generation of Javanese in Suriname were born and raised in Suriname, hence their emotional bonds with the Javanese culture are not as strong as those of the older generation. The abundance of other forms of entertainment, such as radio and film, further makes the 'ties' between the young generation with their Javanese cultural root becoming deteriorated. Movie houses, usually owned by Indian descents, are blossoming in many Javanese districts in Suriname. Furthermore, the aspiration to be equally accepted by the larger society of Suriname who see Javanese culture as having little importance, has pushed the urban youth to embrace the general Suriname lifestyle. ${ }^{44}$

The overwhelming majority of Javanese in Suriname are Muslims. Using Clifford Geertz's (1960) categorization of Javanese society, the Javanese Surinamese can be categorised into a small group of santri and the larger group of abangan. The third category, priyayi is absent, because all the laborers came from the lower class. The santri are men who are knowledgeable about the religion and are pious Muslims. Among the santri are reformist and traditionalist. Whereas the reformist struggle to purify Islam from non-orthodox practices, the traditionalist shows a degree of acceptance to such practices. The abangan are at least nominally Muslims but not necessarily pious, and they mix religion with local culture practices. ${ }^{45}$ Informed by Kroeber's and Redfield's dichotomy of great and little tradition, Annemarie De Waal Malefijt examines syncretic dimension of religious practices among Javanese Muslim in Suriname and the adaptation of religion and culture in a new environment. ${ }^{46}$ Like Malefijt, Dessing shows that the Javanese Surinamese brought virtually all of their cultural practices with them from Java, such as mitoni, slametan, jaran kepang, and else. In addition, the Javanese orientation in praying has been a pretext for Javanese Muslim in Suriname to determine the kiblat, where Muslim orient their face during the prayer. ${ }^{47}$

\footnotetext{
${ }^{44}$ Suparlan, The Javanese in Suriname: Ethnicity in an Ethnically Plural Society; Wengen, The Cultural Inheritance of the Javanese in Surinam.

45 Ibid.

46 Annemarie de Waal Malefijt, "Animism and Islam among the Javanese in Surinam Author," Anthropological Quarterly 37, no. 3 (1964): 149-155..

47 Dessing, Rituals of Birth, Circumcision, Marriage, and Death Among Muslims in the Netherlands.
} 
In Suriname, like other mosques in the Muslim world, mosques have a niche on one side of the mosque wall which indicates the direction of Mecca toward which Muslims face in their prayers. Interestingly, some mosques in Suriname have the niche in the west wall, while some other mosques have it on the east wall.48 In Indonesia, the niche, of course, is in the west wall, because Mecca is west of Java. Meanwhile, in Suriname, if we follow the shortest distance to Mecca, it should be on the east wall. The group that insisted that the niche should be facing west, generally the older generation, called the madep ngilen (from Javanese means 'direction west') group, argued that Javanese in Suriname ought to uphold the tradition. The madep ngetan (from Javanese means 'direction east') group argued to the contrary, saying that the religious requirements ought to come first.

Ichwan notes that there are three major organisations representing different orientation and attitude towards the issue of kiblat among Muslim in Suriname. The reformist Stichting Islamitische Gemeente in Surinam (SIS), founded in 1968, has the east-kiblat and condemns the westward-kiblat. The organisation runs three major mosques: Masjid Nabawi in Paramaribo, Masjid Namiroh in Lelydorp, and Masjid Darul Falah in Blauwgrond. The traditionalist Federatie Islamitische Gemeente Suriname (FIGS) is the organisation with the westward kiblat. This group has maintained the direction of kiblat as with the direction of kiblat in their origin, the Java Island. The Persatuan Jama'ah Islam Surinam (PJIS) takes a mid-stance as it has eastward kiblat as the reformists have, but the group tolerate their fellow Muslim who head to westward in their prayer. ${ }^{49}$

The problem of different kiblat to many extents generated tension between the groups. At the peak of the controversy in the 1950s, it went as far as marriages previously arranged by couples from the opposing groups were broken off, and people refused to honour invitations from the rival group. Nevertheless, time heals, and the schism has been closed, although there we can still find madep nilen mosques today, such as Masjid Pemuda Islam (Islamic Youth Mosque) in Paramaribo. ${ }^{50}$ The number of Muslim who still persist on madem

\footnotetext{
48 Suparlan, The Javanese in Suriname: Ethnicity in an Ethnically Plural Society.

49 Ichwan, "Continuing Discourse on 'Keblat': Diasporic Experiences of the Surinamese Javanese Muslims in the Netherlands."

${ }^{50}$ Erafson, “Ada Dua Kiblat Di Paramaribo,” Gatra, 2006.
} 
ngilen and mosque with eastward kiblat are now decreasing incredibly, possibly due to the extensive access of Javanese Muslim in Suriname to the scripture and the influence of reformist groups in their campaign for orthodox Islam.

Moreover, the division of the madep ngetan and the madep ngulon were brought to the Netherlands. It was estimated that Javanese Suriname migration- living in the Netherlands reaches to 22.306 people They live in many cities in the Netherlands, but mainly in The Hague, Amsterdam, Rotterdam, and Den Bosch. They are also active as establishing organisations with different inclination, like Rahmatullaah Islam (RI) in Brabant, An-Noer in Hoogezand, Al-Jamiatul-Hasanah $(\mathrm{AJH})$ in Rotterdam, Rukun Islam in The Hague, Himmatoel-Islam (HI) in Amsterdam, Sahabatul Islam and Djami'atul Islam Alfatah Nederland (DIAN) in The Hague. These organisations are mainly focusing on religious issues, but there are also institutions that particularly focus on the Javanese cultural elements, thus more syncretic, like Perukunan Sedulur Groningen (PSG) in Groningen, Gotong Royong (GR) in Delfzijl, Pitutur Islam and Pari in The Hague, Sida Mulja (SM) and Perkempalan Bangun Darmaning Agami Islam in Rotterdam. ${ }^{51}$ These Javanese has experienced a double migration after their first relocation from Java to Suriname, later to the Netherlands. However, as in Suriname, the influence of the reformist madep ngetan has also increased among the Javanese Surinamese in the Netherlands. As what is found in Suriname, more Javanese Surinamese in the Netherlands refrained from cultural practices associated with the syncretistic-traditionalist madep ngulon, such as slametan and jaran kepang. This is not to say the demand for travelling back to cultural roots is absent among the Javanese Suriname in the Netherlands. In March 2015, for instance, my institution, IAIN Tulungagung, welcomed a Javanese Surinamese descent living in the Netherlands, Soedirman Moentari, who came to Java for napak tilas (from the Javanese literally means "walking in the footsteps"). Napak tilas in Javanese cosmology is an important concept and practice which underlies re-tracing the footprints of the vanquished and revive it. Moentari's visit without a doubt reflects the practice of "searching for roots" that has been lost for generations. ${ }^{52}$

51 Ichwan, "Continuing Discourse on 'Keblat': Diasporic Experiences of the Surinamese Javanese Muslims in the Netherlands."

${ }^{5}$ Personal communication with Soedirman Moentari, 10 March 2015 
The feeling of lost and the effort to revive the cultural roots do manifest in new homelands, both in Suriname and the Netherlands, but the different place and space certainly curtail their opportunity to perform their cultural practices. For example, Javanese pop music and keroncong maintain their popularity among the Javanese Surinamese, and singers such as Didik Kempot and Mus Mulyadi have the Javanese in the Netherlands market in mind when they produce a new record or show. ${ }^{53}$ Likewise, in the Netherlands, slametans are not held in an open space but are done in small apartments or rented houses. Similar to the problem of kiblat, the controversy on the slametan has caused dissensions among Javanese Muslim in Suriname and the Netherlands. ${ }^{54}$ Van Wengen mentions that it began in the 1930s when the later immigrants from Java arrived. These later immigrants had a frequent contact with an Indonesian reformist Muslim organisation, the Muhammadiyah (established in 1912) that carried out a massive campaign for the purification of Islamic teachings from all foreign elements, mainly from the cultural element framed as adat (custom) and bid'ah (unlawful innovation). ${ }^{55}$ Besides the issue of kiblat which then divided the Javanese into two groups: wong madep ngilen and wong madhep ngetan, those who are intent for purification also attacked the slametan ${ }^{56}$ This controversy sharpened considerably around the 1950s. Some incidents were recorded during this year, from the refusal of each to attend each other's slametan, and marriages formerly arranged between members of families from different groups ended in divorce possibly because of this controversy. ${ }^{57}$ Nevertheless, contemporary the problem recedes from the open controversy, but the reformist's view seems to dominate.

\footnotetext{
53 Meel, "Continuity through Diversity: The Surinamese Javanese Diaspora and the Homeland Anchorage."

54 Khusen, "Contending Identity In The Islamic Ritual: The Slametan among Surinamese Javanese Muslims in The Netherlands."

55 On the Muhammadiyah see Alfian, "Islamic Modernism in Indonesian Politics : The Muhammadijah Movement during the Dutch Colonial Period (1912-1942)," 1969; James L. Peacock, Muslim Puritans: Reformist Psychology in Southeast Asian Islam (Berkeley, Los Angeles \& London: University of California Press, 1978); Mitsuo Nakamura, The Crescent Arises Over the Banyan Tree: A Study of the Mubammadiyah Movement in a Central Javanese Town C. 1910-2010 (2nd Enlarged Edition) (Singapore: ISEAS, 2012).

56 Ichwan, "Continuing Discourse on 'Keblat': Diasporic Experiences of the Surinamese Javanese Muslims in the Netherlands."

${ }^{57}$ Wengen, The Cultural Inheritance of the Javanese in Surinam.
} 


\section{Conclusion}

The above discussion argues for the translocal dimension Islam Jawa. Its approach is different from majority studies on Islam in Java and offers a new light on the relationship between globalisation and local identity and culture. It further argues that the notion of Islam Jawa shall not be limited to the mainstream view that tends to see it as localised form of Islam but to include also the expression of Islam Jawa beyond the geospatial-limits. Islam Jawa in its new homelands stresses the continuity of tradition outside the state boundaries and the imagining for being Javanese and Muslim outside the Island of Java. The continuity of tradition in somewhere outside geographical locatedness contests the idea that local expression is "a local" in a geographical sense. The expression of Islam Jawa in Suriname and the Netherlands is without a doubt an ample example of how tradition is translated into new contexts and homelands. The translation of culture and tradition is not something novel because hundreds of tradition are manifested, maintained and even creatively 'invented' -to follow Hobsbawm's term-58 in modern times where the limits of boundaries have been put into question, particularly when multiple forms of culture and tradition are becoming connected and entangled. Nevertheless, this is not to say that tradition is something fixed and absolute. Tradition is always in the contest, negotiated, and subjects of changes as does Islam Jawa in its geographical origin ${ }^{59}$ and somewhere else in its new homelands. []

\section{References}

\section{Books and Articles}

Alatas, Ismail Fajrie. "Aligning the Sunna and the Jamā'a: Religious Authority and Islamic Social Formation in Contemporary Central Java, Indonesia." The University of Michigan, 2016.

\footnotetext{
${ }^{58}$ Eric Hobsbawm and Terence Ranger, "Introduction: Inventing Traditions," in The Invention of Tradition, ed. Eric Hobsbawm and Terence Ranger (Cambridge: Cambridge University Press, 1983), 1-14.

${ }^{59}$ For the abangan tradition in contemporary Indonesia, see for example R W Hefner, "Where Have All the Abangan Gone? Religionization and the Decline of NonStandard Islam in Contemporary Indonesia," in The Politics of Religion in Indonesia: Syncretism, Orthodoxy, and Religious Contention in Java and Bali, ed. Michel Picard and Rémy Madinier (London and New York: Routledge, n.d.), 71-91.
} 
. "Pilgrimage and Network Formation in Two Contemporary Bā'alawī Ḥawl in Central Java." Journal of Islamic Studies (May 13, 2014).

Alfian. "Islamic Modernism in Indonesian Politics: The Muhammadijah Movement during the Dutch Colonial Period (1912-1942)," 1969.

Allen, Pamela. "Diasporic Representations of the Home Culture: Case Studies from Suriname and New Caledonia." Asian Ethnicity 16, no. 3 (2015): 353-370.

. "Indonesians Speaking French." Inside Indonesia. Last modified 2010. Accessed February 2016. http://www.insideindonesia.org/indonesians-speaking-french.

- "Javanese Cultural Traditions in Suriname." Review of Indonesian and Malaysian Affairs 45, no. 2011 (2012): 199-223.

AlSayyad, Nezar, and Manuel Castells. Muslim Europe or Euro-Islam: Politics, Culture, and Citizenship in the Age of Globalization. Lexington: Lexington Books, 2002.

Anjum, Ovamir. "Islam as a Discursive Tradition: Talal Asad and His Interlocutors." Comparative Studies of South Asia, Africa, the Middle East 27, no. 3 (2007): 656-672.

Appadurai, Arjun. Modernity at Large: Cultural Dimensions of Globalization. Minneapolis: University of Minnesota Press, 1996.

Asad, Talal. The Idea of an Anthropology of Islam. Washington DC: Centre for Contemporary Arab Studies, 1986.

Babcock, Tim G. Kampung Jawa Tondano: Religion and Cultural Identity. Yogyakarta Indonesia: Gadjah Mada University Press, 1989.

Barrett, Paul. American Islam: The Struggle for the Soul of a Religion. New York, etc.: Picador, 2007.

Beatty, Andrew. Varieties of Javanese Religion. An Anthropological Account. New York: Cambridge Univiversity Press, 1999.

Dessing, Nathal M. Rituals of Birth, Circumcision, Marriage, and Death Among Muslims in the Netherlands. Leuven: Peeters, 2001.

Eickelman, Dale F. Moroccan Islam: Tradition and Society in a Pilgrimage Center. Texas: University of Texas Press, 1981.

Erafson. “Ada Dua Kiblat Di Paramaribo.” Gatra, 2006. 
Ewing, Katherine Pratt. Shari at and Ambiguity in South Asian Islam. Berkeley: University of California Press, 1988.

Foucault, Michel. "Different Spaces." In The Essential Works of Michel Foucault, 1954-1984, edited by James D. Faubion, 175-185. New York: The New Press, 1997.

Freitag, Ulrike, and Achim von Oppen. "Introduction: 'Translocality': An Approach to Connection and Transfer in Area Studies." In Translocality: The Study of Globalising Processes from a Southern Perspective, edited by Ulrike Freitag and Achim von. Oppen. Leiden \& Boston: Brill, 2010.

Geertz, Clifford. Islam Observed: Religious Development in Morocco and Indonesia. A Phoenix book. Chicago: University of Chicago Press, 1968.

- The Religion of Java. Illinois: The Free Press of Glenco, 1960.

Gellner, Ernest. "Muslim Society." Cambridge: Cambridge University Press, 1981.

Gilsenan, Michael. Recognizing Islam: Religion and Society in the Modern Middle East. London: I. B. Tauris, 1990.

Hannerz, Ulf. "Transnational Research." In Handbook of Methods in Cultural Anthropology, edited by H. Russell, Bernard, 235-258. Walnut Creek: Altamira, 1998.

Hefner, R W. "Islam, State, And Civil Society : ICMI and the Struggle for the Indonesian Middle Class." Indonesia 56 (1993): 1-35.

- "Where Have All the Abangan Gone? Religionization and the Decline of Non-Standard Islam in Contemporary Indonesia." In The Politics of Religion in Indonesia: Syncretism, Orthodoxy, and Religious Contention in Java and Bali, edited by Michel Picard and Rémy Madinier, 71-91. London and New York: Routledge, n.d.

Hendrix, E.M., and M.A. van Waning. "De Javaanse Moslims in Suriname: Een Kwalitatief Onderzoek Anno 2009." Universiteit Utrecht, the Netherlands, 2010.

Hilmy, Masdar. "Islam and Javanese Acculturation: Textual and Contextual Analysis of the Slametan Ritual." McGill University, 1999.

Ho, Engseng. The Graves of Tarim: Genealogy and Mobility Across the Indian 
Ocean. California World History Library. California: University of California Press, 2006.

Hobsbawm, Eric, and Terence Ranger. "Introduction: Inventing Traditions." In The Invention of Tradition, edited by Eric Hobsbawm and Terence Ranger, 1-14. Cambridge: Cambridge University Press, 1983.

Hodgson, Marshall G. S. The Venture of Islam. The Expansion of Islam in the Middle Periods: Conscience and History in a World Civilization (Volume 2). Chicago: University of Chicago Press, 1974.

Hoefte, Rosemarijn. In Place of Slavery: A Social History of British Indian and Javanese. Miami etc.: University Press of Florida, 1998.

2008. Accessed January 9, 2016.
http://www.insideindonesia.org/the-javanese-of-suriname.

Ichwan, Moch Nur. "Continuing Discourse on 'Keblat': Diasporic Experiences of the Surinamese Javanese Muslims in the Netherlands." Sharqiyyat 11, no. October 1997 (1999): 101-119.

Khusen, Moh. "Contending Identity In The Islamic Ritual: The Slametan among Surinamese Javanese Muslims in The Netherlands." Al-Jami'ah: Journal of Islamic Studies 43, no. 2 (2005): 283-308.

Koesoebjono, Santo. "Javanese in Suriname Strive to Preserve Origins." The Jakarta Post, 1999.

Malefijt, Annemarie de Waal. "Animism and Islam among the Javanese in Surinam Author." Anthropological Quarterly 37, no. 3 (1964): 149-155.

Mandaville, Peter G. Transnational Muslim Politics: Reimagining the Umma. Oxon: Routledge, 2003.

Meel, Peter. "Continuity through Diversity: The Surinamese Javanese Diaspora and the Homeland Anchorage." Wadabagei: A Journal of the Caribbean and Its Diaspora 13, no. 3 (2011): 95-134.

Nakamura, Mitsuo. The Crescent Arises Over the Banyan Tree: A Study of the Muhammadiyah Movement in a Central Javanese Town C. 1910-2010 (2nd Enlarged Edition). Singapore: ISEAS, 2012.

Peacock, James L. Muslim Puritans: Reformist Psychology in Southeast Asian 
Islam. Berkeley, Los Angeles \& London: University of California Press, 1978.

Redfield, Robert. Peasant Society and Culture. Chicago: University of Chicago Press, 1956.

Rosander, Eva Evers, and David Westerlund. African Islam and Islam in Africa: Encounters between Sufis and Islamists. Ohio: Ohio University Press, 1997.

St-Hilaire, Aonghas. "Ethnicity, Assimilation and Nation in Plural Suriname." Ethnic and Racial Studies 24, no. 6 (January 2001): 9981019.

Suparlan, Parsudi. The Javanese in Suriname: Ethnicity in an Ethnically Plural Society. Arizona: Program for Southeast Asian Studies, Arizona State University, 1995.

Wengen, G. D. van. The Cultural Inheritance of the Javanese in Surinam. Leiden: E.J. Brill, 1975.

Widjanarko, Putut. "Homeland, Identity and Media: A Study of Indonesian Transnational Muslims in New York City." Ohio University, 2007.

Wolfowitz, Clare. Language Style and Social Space: Stylistic Choice in Suriname Javanese. Urbana: University of Illinois Press, 1991.

Woodward, Mark. Islam in Java: Normative Piety and Mysticism in the Sultanate of Yogyakarta. Arizona: University of Arizona Press, 1989.

Woodward, Mark R. “The 'Slametan': Textual Knowledge and Ritual Performance in Central Javanese Islam." History of Religions 28, no. 1 (1988): 54-89. 
Maftukhin

394 JOURNAL OF INDONESIAN ISLAM

VOLUme 10, Number O2, DECEMBER 2016 